\title{
ORÍGENES DE LA DIABLADA
}

\section{Omar Aramayo Cordero ${ }^{1}$}

Los bolivianos se arrogan haber creado la Diablada. Nada más falso. Ningún historiador boliviano, antropólogo, o folklorólogo, podría precisar a ciencia cierta, cuándo, en qué momento preciso, en qué año, se produjo esta creación artística, supuestamente en Oruro. Ningún científico social, pero sí, seguramente un político 0 un grupo de comerciantes, con ansias de dividendos.

Pero vayamos por partes y cucharadas, y veamos a la Diablada como traje, música, y danza; tres partes articuladas por una idea matriz, la concepción de lo infernal. Lo tormentoso diabólico, lo aterrador y horripilante, convertido en danza. La Diablada, como liturgia popular, pagana y catártica. Esto tiene dos partes: lo demoniaco que viene de España, del catolicismo, el terror utilizado por la evangelización, que no es invención boliviana. Nadie puede decir que los bolivianos inventaron el terror del infierno, lo grotesco, ni siquiera Alighieri con su portentosa imaginación podría reclamarlo, todo viene de la Biblia y de mitologías anteriores, de los demonios de Babilonia, del macho cabrío, del dios Pan, que aterrorizaba los bosques. La idea principal de la Diablada es europea.

Ese instrumento de la evangelización se divulgó a través de la verba, por cierto, pero también a través de la tumultuosa pintura colonial, de los murales de sus templos, como el de San Pedro de Andahuaylillas, Cusco, conocido como la Capilla Sixtina de América, donde aparece el mural de Riano, pintado en 1626; y que ha sobrevivido al tiempo. En términos generales la imaginería de la Diablada es cristiana, los diablos mayores y menores, los ángeles, el bestiario del infierno. Los ibéricos reclaman los siete capitales como suyos, tan presentes en la versión boliviana de la Diablada y tan omitidos en la Diablada puneña. España nos trajo a Cristo pero también las nociones de culpa, pecado, y sumisión del espíritu ante ellos.
Lo que es americano, andino, aymara, indio y mestizo, es el nuevo sentido que adquiere esa imaginería tradicional católica, que surge como expresión de rebelión, como espíritu revolucionario del pueblo andino ante el sometimiento hispano, ante su ideología represiva y opresiva. El terror se convierte en alegría, en euforia; los diablos marchan de contento, de plenitud, no dan miedo sino satisfacción, la satisfacción que produce el arte. La Diablada es una expresión del humor, y esa es la Diablada puneña, altiplánica, y que comparte con la versión boliviana. Danzar ante la Virgen de la Candelaria, en el templo de San Juan, en el kacharpari, es revolucionario, allí se rompe el paradigma cristiano y se crea otro, el paradigma andino, los diablos no son los ángeles arrojados al infierno, son los espíritus que se reconcilian con la fe, aunque el obispo del Opus Dei no lo entienda de esa manera.

¿En qué momento histórico se produce esa rebelión del espíritu, y contra España? Esa es la pregunta que anima este texto, para señalar a través de esa respuesta algunos derroteros que nos permitan acercarnos al espíritu y a los orígenes de la danza, (y a su propiedad, como patrimonio nacional).

La Diablada y la Morenada tienen su origen en la desacralización de los trajes religiosos, la ropa de culto de los curas y la ropa de los santos, en el siglo 18, en el contexto de la gran rebelión encabezada por José Gabriel Túpac Amaru y continuada en el Altiplano por Diego Cristóbal Túpac Amaru, Andrés Túpac Amaru, Julián Túpac Katary y más de cien mil quechuas y aymaras.

En aquellos días, una manera de huir de los pueblos, para los españoles, era vestido de cura y mejor en traje de culto, hasta que los aymaras y quechuas se percataron que también ellos podían profanar, usar esos trajes para sus fines cuando lo quisieran, y que lo sagrado hispano no lo era tanto, por eso los templos de Chucuito, Juli o Pomata, producto del degollamiento de

\footnotetext{
${ }^{1}$ Poeta, narrador y periodista. Iniciador de los estudios de la poesía de Carlos Oquendo de Amat y Gamaliel Churata. Autor de un libro sobre el pintor Víctor Humareda, de la novela "Los Túpac Amaru 1572-1825" y del libro de cuentos "El Gallo de Cristal". Director del Fondo Editorial de la Universidad Alas Peruanas hasta el 2016. Dedica su vida a la defensa del Lago Titicaca y a la defensa de la originalidad de las danzas puneñas. E-mail: omararamayoamazonas@gmail.com
} 
la población blanca, se convirtieron en verdaderas piscinas de sangre. En Paucartambo un quechua alzado, de la noche a la mañana se tonsuró y se hizo obispo; en el alto Perú, uno de ellos tomó un cáliz, renegó de Cristo y sirvió coca y chicha entre los suyos. Nunca antes, ni siquiera en el Taqui Onkoy se había puesto el mundo de cabeza. Los quechuas y aymaras tomaron las armas, pero también los trajes de la iglesia.

¿De dónde vienen los trajes recamados de piedras semipreciosas, bordados con hilos de plata, y en términos generales bordados con hilos de metal? De la ropa sagrada de las iglesias y más tarde de la ropa de los toreros. Trajes de luces. De dónde más habría de venir ¿de Venus, de Marte? Claro que en la actualidad ya no hay trajes recamados de piedras semipreciosas ni bordados en hilos de metal, todo es plastiquería que imita a los trajes tradicionales, telas y piedras falsas importadas de Brasil. Los bolivianos las compran por mayor en el Brasil y los puneños van a importarlas de Bolivia. ¿Ese es el patrimonio que reclaman?

La máscara y el traje son y traen parte de la historia. Algunos, seguramente, piensan que la Diablada nació con la máscara actual, como se ve en la televisión, no es verdad, en doscientos años ha cambiado hasta casi olvidar sus primeras formas, su estructura, sus facciones, sus dimensiones, y hasta la forma de sus cuernos.
Su transformación no ha podido ser más dinámica, desde aquellas con las que se bailaba en los años 20 del siglo pasado y que fueron registradas por los pintores indigenistas como Zegarra Villar, y que eran muy simples. En los cincuenta y sesenta, la máscara se enriquece a más no decir y marca su mejor momento, son máscaras de yeso, muy pesadas pero muy hermosas; a la manera de las cabezas trofeo Pucará lucen pequeñas cabezas unas sobre otra hasta veinticinco o más. Aun se pueden ver algunas como objetos de ornato.

Luego entran las de lata, avasalladoramente, en mi infancia vi algunas pequeñas fábricas en Puno, la más importante la del señor Velásquez, más conocido como Karrkarr, que vivía en la avenida El Sol. Muchas veces atisbé en esas pequeñas fábricas el ejercicio de la tijera, la destreza del artesano, la soldadura y luego la pintura, era fascinante para mí. Las de lata desplazaron totalmente a las de yeso, que eran artesanales, en cambio las de ahora son industriales, y sin gracia particular, a no ser la repetición del gesto diabólico. Este impromptus estético se dio entre otros motivos por la explosión demográfica de nuestros pueblos, lo singular dio paso al consumo masivo, a las grandes comparsas. No es lo mismo hacer veinte máscaras que cientos de ellas.La máscara primitiva del Diablo es muy interesante, bella y simple, de lata; la actual no, por lo menos, no es origi-

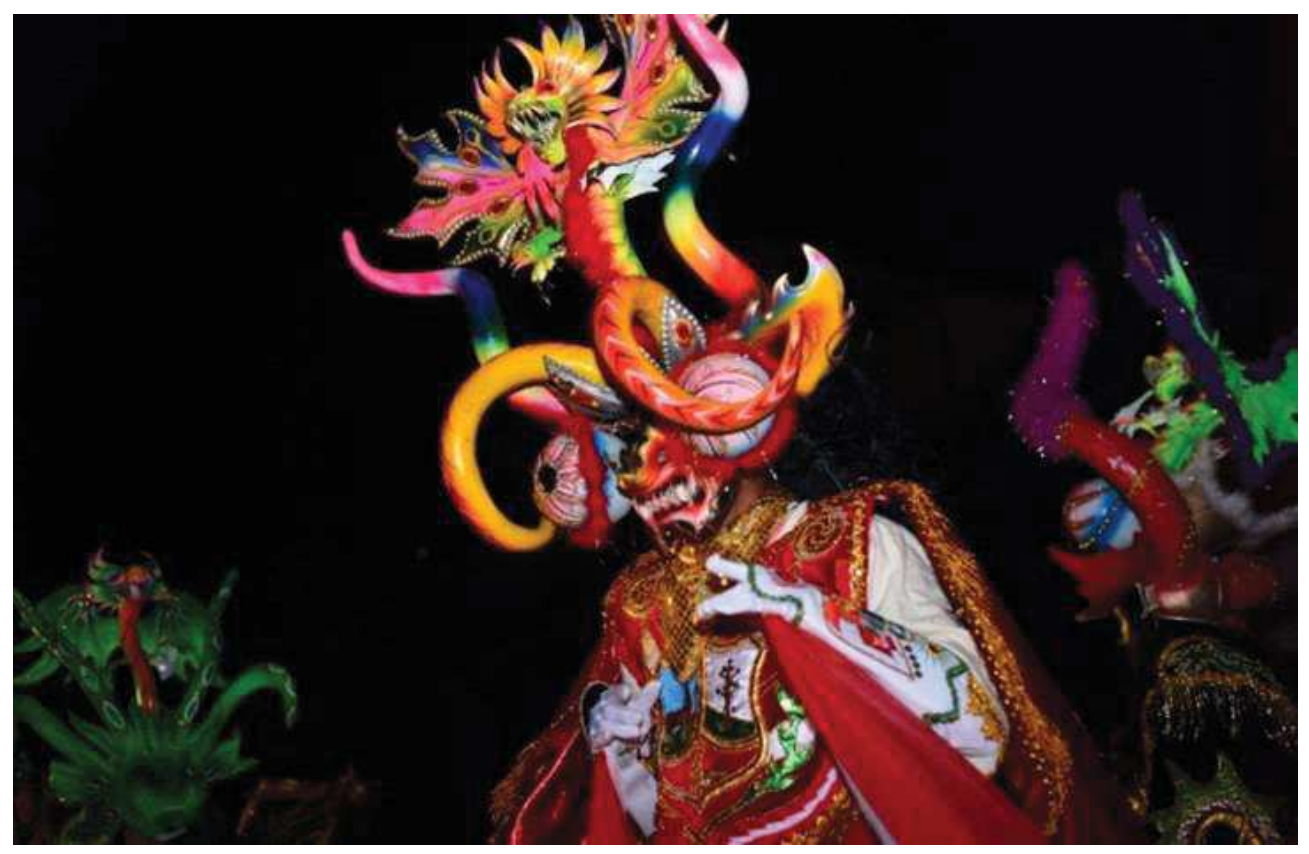

La máscara de la Diablada de Puno, tiene gran influencia oriental Foto: Uriel Alexis Montufar Butrón 
nal, en Venezuela hay muy parecidas, casi idénticas. Los colmillos, las orejas, los cuernos, la nariz recortada, como si los hubieran copiado en un taller de Puno o de Bolivia, son de origen afro, y a nadie se le ocurre que habría que ir a Venezuela a reclamarlas como patrimonio peruano boliviano.

La máscara de Diablo puneño (y boliviano) tiene gran influencia oriental, en ella se ve toda la dragonería mitológica de la vieja China, su iridiscencia plena, polarmente diferente a la gracia y austeridad andina, (a no ser los aguayos y todo el arte textil aymara) y eso viene de los años cincuenta, cuando la Diablada se hace fastuosa y multitudinaria. Espectacular.

¿Dónde nació la idea de una máscara como la original, de los orígenes, con sus dos pequeños cuernos orientados hacia su espacio interior? Máscara que no es de gran complejidad, quién sabe del sueño de un artista, o tal vez de las máscaras de diablos que Pancho Fierro pintaba en el siglo XIX, el Son de los Diablos, aunque antes ya estaba en otra danza negra que el obispo Baltasar Martínez Compañón registra en los años ochenta del siglo XVIII, allí se puede ver un antecedente inmediato y claro de la Diablada puneña, con el ángel tal como viste hoy, los diablos con roncadoras o espuelas; y digo e insisto en lo de danza negra, porque uno de los danzarines músicos pulsa una quijada de burro, instrumento de origen afro peruano.

Cualquiera de las danzas de diablos que hay en el Perú, que son muchísimas, en cada provincia hay una, pudo ser el origen de la actual y espectacular Diablada puneña que los bolivianos reclaman como patrimonio nacional. La máscara de los Sajhras de Paucartambo, por ejemplo, que son coloniales, originales, complicadas, brillantes y chillones, de parecido increíble y casual con los diablos balineses (¿qué relación había en el Perú del siglo XVI y el sur este asiático?) Podría ser el origen de la Diablada puneña, es lo que más se acerca. Los bolivianos ilusoriamente asumen que la Diablada nació tal como es hoy, y eso no es verdad, entiendan, es un largo proceso histórico y colectivo, que tiene su origen en varias vertientes. El complejo adánico es infantil, y ese afán de estarse contemplando el ombligo a cada instante es enfermizo, los horizontes existen y por allí transita gente.

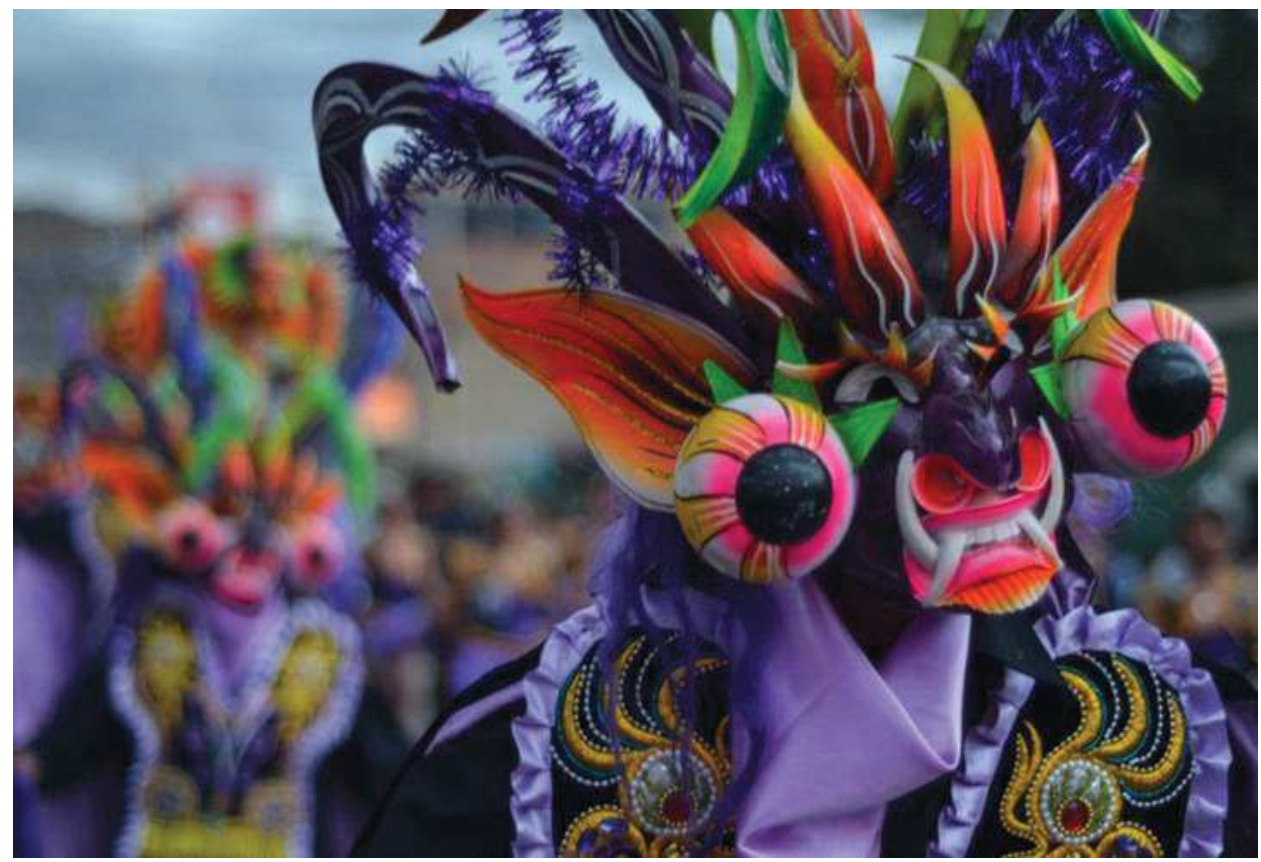

El origen de la Diablada tiene varias vertientes, responde a un largo proceso histórico y colectivo Foto: Uriel Alexis Montúfar Butrón 
Si la máscara es compleja el traje también lo es, la capa, la sobre capa, la pechera, las palcas. Su bordado en hilos metálicos y su recamado, viene de las iglesias, de la ropa sacra, es parte de la rebelión ideológica que sobrevino ya en el siglo XIX como reflujo de la gran rebelión de los Túpac Amaru. Es necesario, analizar cada una de las partes mencionadas y lo haremos en otro momento. Lo que sí debemos señalar es que en la personalidad del caporal puneño, en su prestancia, en su arrogancia, está el impromptu feudal, están las roncadoras, las espuelas del jinete de caballo fino, el caballo del gamonal. Eso no está en el diablo boliviano.

La música es otro tema que debe ser señalado como parte de la controversia. La Diablada es una danza marcial, de grandes zancos, es decir de pasos altos 0 saltos; es una marcha simple elemental, ejecutada con instrumentos europeos, muchos de los cuales terminan de construirse tal como los conocemos hoy en el siglo XIX. Después de observar por años las danzas nativas, no creo que en el Alto Perú o en el Perú, se hayan desarrollado en la antigüedad prehispánica estos tiempos musicales, los de la marcha militar europea; salvo que los investigadores bolivianos demuestren lo contrario.

Las bandas militares en la mayor parte de los países de América Latina aparecen en el siglo XX, con gran influencia en la sensibilidad popular, Juan Gonzalo Rose, por ejemplo, nos deja ver que el vals peruano se desprende de las retretas de las bandas militares, de los valses austriacos que interpretaban. El saxofón de gran influencia en la música huancaína, al extremo que no se explica un Huaylarsh sin él, llega a América, por un hecho del azar, su inventor y sus fabricantes al no tener la respuesta a sus ventas lo rematan para agotar su producción, hoy se ha hecho imprescindible. Los alemanes que se refugiaron en Bolivia, después de la Segunda Guerra Mundial, y que asesoraron a su ejército, implementaron en Bolivia bandas militares impresionantes, naturalmente que aquello determinó el desarrollo de sus bandas populares. ¿Es eso lo que reclaman? En los años cincuenta, igualmente, la Banda de la Guardia Republicana en el Perú, produjo música andina muyhermosa.

La participación de una banda tan estructurada y creativa como la del ejército norteamericano, bajo la batuta de Glen Miller, contribuyó a levantar la moral de su ejército. El estruendo de los instrumentos de bronce copa el aire, conmocionan, comprometen la emotividad colectiva, crean una atmósfera muy distinta a la de la guitarra o la del arpa, equiparable gracias a los altoparlantes después de los cincuenta. Danzas tumultuarias como la Diablada o la Morenada jamás podrían marchar con una guitarra, un tambor o una quijada de burro. Las estudiantinas ya tienen problemas para recorren las calles, o los Kajelos con sus charanguitos cuando van por las calles, una es la música del poblacho otra la de la urbe.

La primera banda militar que llega al Cusco, con el ejército español para reprimir la rebelión de los Túpac Amaru, fue en enero de 1781; causó profunda conmoción en la población quechua. También debemos anotar

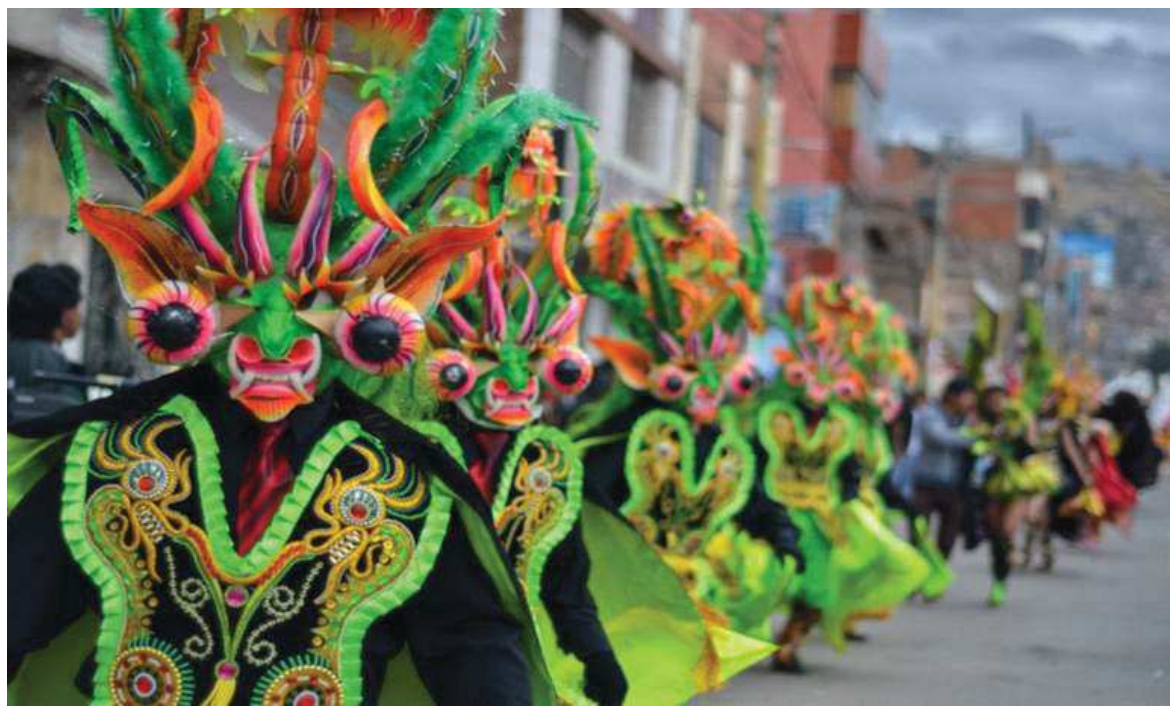

La Diablada, danza de multitudes en Puno Foto: Uriel Alexis Montufar Butrón 
a las cornetas de los ejércitos libertadores, tan caras a la sensibilidad popular, que pronto fueron asimiladas por el folklore. En fin, lo cierto es que todo esto es foráneo; ¿qué reclaman entonces los bolivianos? Los huayñitos centenario y migrantes, que son de aquí y son de allá, que los lleva el viento o los arrieros, y a los que solo se les ha cambiado de tiempo musical.

La danza de la Diablada es elemental, tal vez su gracia radica en esa simplicidad. No tiene la riqueza, por ejemplo, de los Chokelas, danza milenaria, compleja, que habla de los primeros tiempos del ser humano en territorio americano, con una variedad de tiempos, que bajo la visión europea puede ser considerada como una suite. Pero no tiene la "suerte" de ser interpretada por una banda militar, y más bien ha ingresado en la opacidad de las danzas en extinción, porque la sociedad agraria se ha convertido en industrial. No tiene la elaboración colonial de las danzas de Paucartambo ni de los Chonguinos de Huancayo.

Por cierto, que nada de esto habría podido suceder en un lugar donde la danza no fuese de vital importancia, como lo fue en los pueblos prehispánicos. La población que encontraron los españoles fue de bailarines, basta revisar el diccionario de Bertonio para ver la cantidad de danzas que consigna el ilustre jesuita, desaparecidas hoy.

¿Qué tiene la Diablada que la ha hecho danza de multitudes? Lo espectacular, lo gimnástico, la vitalidad, sensaciones y emociones que atrapan al bailarín, lo hacen vivir, se eleva en cuerpo y alma en una música marcial nutrida del sentimentalismo aymara, de su profundidad anímica, de su sentido panteísta. El despla- zamiento coreográfico que se desarrolla en Puno y que no existe en Bolivia, le da un valor agregado a ese sentido espectacular, orgiástico, colorido, brillante. Nadie ha reconocido hasta el momento, en Puno, al aporte creativo de los coreógrafos de los conjuntos.

La Diablada es una danza mestiza, puneña, Enrique Cuentas Ormachea decía que Diablada y Morenada se habían creado en la época de la explotación de las minas de Laykakota, alrededor de 1668, en medio de la confrontación de andaluces y vizcaínos, los primeros crearon la Diablada y los segundos la Morenada.

Hay que considerar, que así como las danzas son dinámicas, se transforman, también los pueblos, la gente. Hay que recordar que alrededor de las minas de Laykakota, de su actividad económica, se desarrolló la vida con toda su complejidad. Hay que recordar también, que casi al finalizar la colonia, la gran rebelión se orquestó desde Azángaro, por lo tanto el traslado de una gran población, Azángaro fue su centro hegemónico. La Paz y Oruro, no siempre fueron la metrópolis de la cultura Andina. Es innegable el aporte de los artesanos y bailarines bolivianos a esta danza puneña. En verdad, su patria es el altiplano, pero los orígenes, es decir sus raíces, están en el tiempo, y están en Puno; y sería de una mezquindad horrorosa ir a Bolivia y decirles que no la bailen.

Queda mucho pan por rebanar, y en el tintero se me quedan muchos temas y muchas ideas. Por ejemplo una gran nota sobre la Diablada del Conjunto de Sicuris del Barrio Mañazo. 